\title{
LATE ONSET OF ORAL CHRONIC GVHD
}

\author{
Manifestação tardia do GVHD oral crônico
}

Paulo Sérgio da Silva Santos, Fábio Luiz Coracin, Fábio Daumas Nunes, Marina Gallottini Magalhães

\begin{abstract}
Chronic graft-versus-host disease is the major late complication following allogeneic hematopoietic stem cell transplantation (HSCT), and the major cause for morbidity and loss of quality of life in HSCT long-term survivors. Oral involvement accounts for around 53\% - 70\% of bone marrow and peripheral blood stem cell recipients, respectively. We report a case of late onset oral chronic GVHD and discuss the role of the oral health care providers in the early diagnosis and management of this disease. Moreover, oral cGVHD development 4 years after transplantation and coincident with withdrawing immunosuppression is most uncommon and shows the importance of tracking the involvement of the oral cavity after allogeneic transplantation.
\end{abstract}

Keywords: Graft Rejection, Mouth Diseases, Bone Marrow Transplantation

Instituição:

Departamento de Patologia Bucal da Faculdade de Odontologia da Universidade de São Paulo - São Paulo / SP

\section{Correspondência:}

Paulo Sérgio da Silva Santos

Av. Prof. Lineu Prestes, 2227 - Cidade Universitária - São Paulo / SP - CEP: 05508-000 Brasil

Tel.: (11) 30917902

E-mail: paulosergiosilvasantos@gmail.com

Recebido em: 03.09.2008

Aceito em: 30.09 .2008

\section{INTRODUCTION}

Hematopoietic stem cell transplantation (HSCT) is a therapeutic modality that still provides chances for healing several hematological malignancies. ${ }^{1}$ Although immunosuppression facilitates the bone marrow transplantation, it also causes a series of side effects, among which a complication known as graft-versus-host-disease (GVHD). ${ }^{2}$

Historically, GVHD has been divided into acute (aGVHD) and chronic (cGVHD), with acute GVHD occurring in the first 100 days after transplantation and chronic GVHD, after such period. Advancements in HSCT in the past 20 years have altered the previous classification based on clinical and histological features of both acute and chronic GVHD. ${ }^{3}$ Chronic graft-versus-host disease is the major late complication following allogeneic HSCT, and the major cause of morbidity and loss of quality of life among HSCT long-term survivors. ${ }^{4}$ Oral involvement is observed in around $70 \%$ of peripheral blood stem cell recipients and 53\% of bone marrow recipients. ${ }^{5}$

Clinical manifestations of chronic GVHD may occur in the oral mucosa, skin, liver, gastrointestinal tract and lymphoid system. The oral mucosa may be the first site of manifestation of the disease, suggesting that other organs should be investigated. ${ }^{6}$ Objective findings in the oral cavity were reported by Schubert (1984), including erythema (73\%) and oral lichenoid lesions (36\%) as major clinical signs, while ulcerative lesions were not frequent in GVHD patients. ${ }^{7,8}$ Clinically, chronic GVHD of the oral mucosa can be divided into grades 1,2 or 3 , according to the classification proposed by Akpek. in 2001. Code 1 is defined as no clinical evidence of cGVHD; code 2 is the clinically evident oral cGVHD (severe dry mouth, food sensitivity, lichenoid mucosal changes and/or erythema, and/or ulcer/blisters), and code 3 is used when patients required pain medication and/or feeding tube, secondary to severe oral cGVHD. ${ }^{9}$ 
The oral manifestations of chronic GVHD may be associated with those in other regions of the body, such as dermatitis, hepatitis and gastroenteritis (diarrhea and abdominal pain). However, they can often be the first sign of the disease. Histological analysis helps to establish the diagnosis of GVHD. ${ }^{10}$ A working group from the US National Institutes of Health has recently published a consensus which sets a discussion on the histopathological changes brought about by GVHD in various tissues, including the oral epithelium and minor salivary glands. This document set the minimum criteria for a histological diagnosis of GVHD and classified the diagnosis as: "no GVHD", "possible", "probable" and "GVHD"."1

The purpose of this study is to report a case of four years late onset of oral chronic GVHD and to discuss the role of oral health care providers in the early diagnosis and management of this disease.

\section{CASE REPORT}

A 33-year-old white male patient who had undergone allogeneic hematopoietic stem cell transplantation in 2001 due to severe aplastic anemia was referred to the Special Care Dentistry Center, University of São Paulo (CAPE/FOUSP) in 2005, complaining of dry mouth and lesions in the oral mucosa. The conditioning regimen included high-dose chemotherapy without total body irradiation. Since the transplantation, patient had been treated with high-dose of prednisone ( $2 \mathrm{mg} / \mathrm{Kg} /$ day) and cyclosporine $(12.5 \mathrm{mg} / \mathrm{Kg} /$ day) for 4 years. No acute GVHD was presented, thus 2 months after ceasing his medications, he showed clinical features suggestive of chronic GVHD presented 4 years after the BMT, including oral dryness, white plaques on the buccal mucosa and palate, and ulcers on the lip and lateral border of the tongue (Figure 1 and 2). According to the clinical classification proposed by Akpek in 2001, the disease was graded as code 2. A biopsy of the oral mucosa was performed including the right lower lip mucosa and minor salivary glands, in order to confirm the diagnosis of cGVHD. Histopathological examination revealed basilar vacuolopathy, spongiosis, exocytosis of lymphocytes in the epithelium, and the presence of a generalized lymphocyte infiltration (interstitial and bandlike) throughout the lamina propria. The analysis of minor salivary glands showed

Figure 1. Oral lichenoid lesions in buccal mucosa

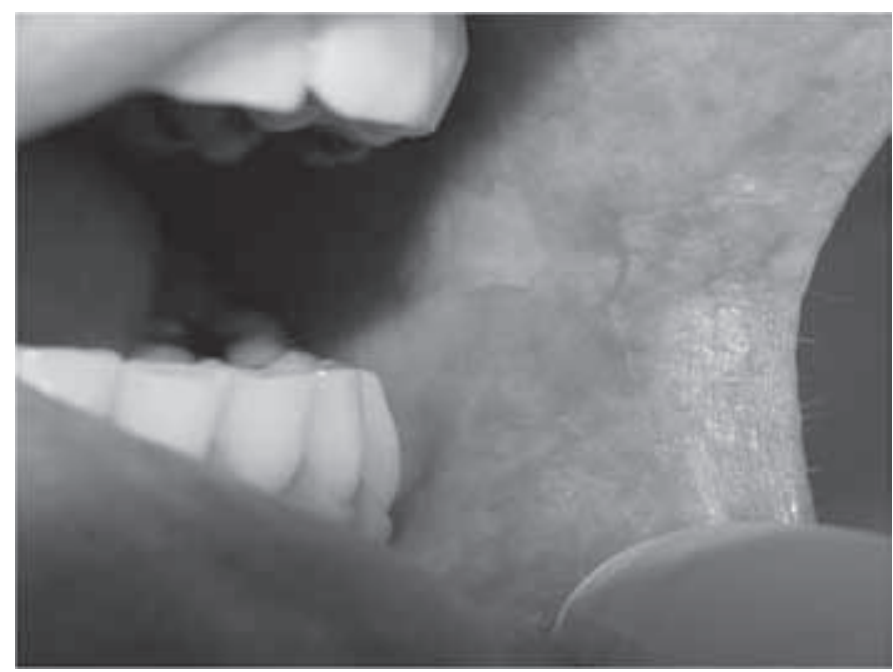

chronic infiltration with mixed cells in the periductal region and lymphocytes migrating into acinar units, as well as periductal fibrosis and loss of polarity of ductal epithelial cells (Figure 3, 4 and 5). It is consistent with the diagnosis of "probable chronic GVHD"[11]. Based on the histopathology results, the patient's medical history and the clinical examination, the diagnosis of cGVHD was established. Topical treatment with betamethasone $50 \mathrm{mcg} /$ dose (beclomethasone dipropionate, GlaxoSmithKline) was initiated three times a day for three months. There was partial remission of the lesions and a decrease in the patient's symptoms after three months. At the end of a period of one year follow-up, the patient was free from oral lesions. Differential diagnosis with local CMV infection, immunohistochemistry was negative for CMV antibody in both the oral mucosa and minor salivary glands (data not shown). Additionally, no fungal infections were observed.

\section{DISCUSSION}

The frequent and careful assessment of clinical signs in the oral cavity and the histological examination of the findings are important to the diagnosis and prognosis of cGVHD. ${ }^{12}$ This is important because cGVHD reduces the quality of life of long-term survivors. In the case reported here, the patient developed oral chronic GVHD four years ( \pm 1400 days) after withdrawing immunosuppression.

We decided to use Bethametasone $50 \mathrm{mcg} / \mathrm{dose}$ (3 times/day) according to reported by França, who has proven to be effective in the topical treatment of the clinical features of oral cGVHD, ${ }^{13}$ leading to an effective response in the oral symptoms.

Our patient presented severe xerostomia, pain, and oral lichenoid lesions. After topical treatment with beclomethasone, the oral lichenoid lesions and pain subsided; however, dry mouth complaints still remained. Dry mouth could be caused by the cumulative effects of the conditioning regimen 14 and persistent damage in the salivary glands caused by chronic GVHD. ${ }^{15}$

Figure 2. White plake in hard palate

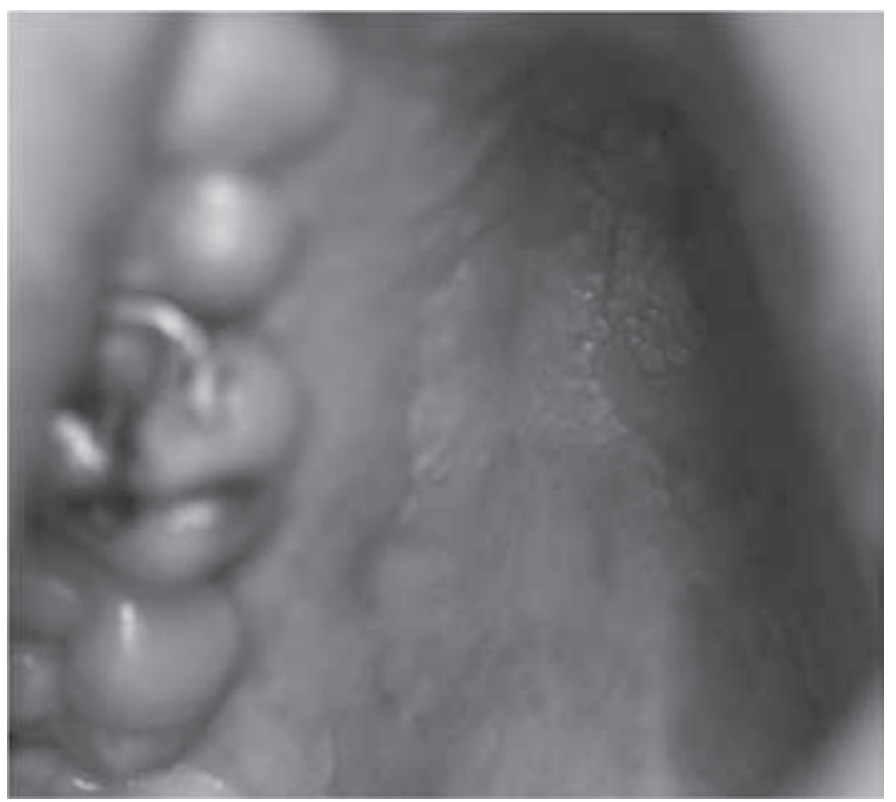




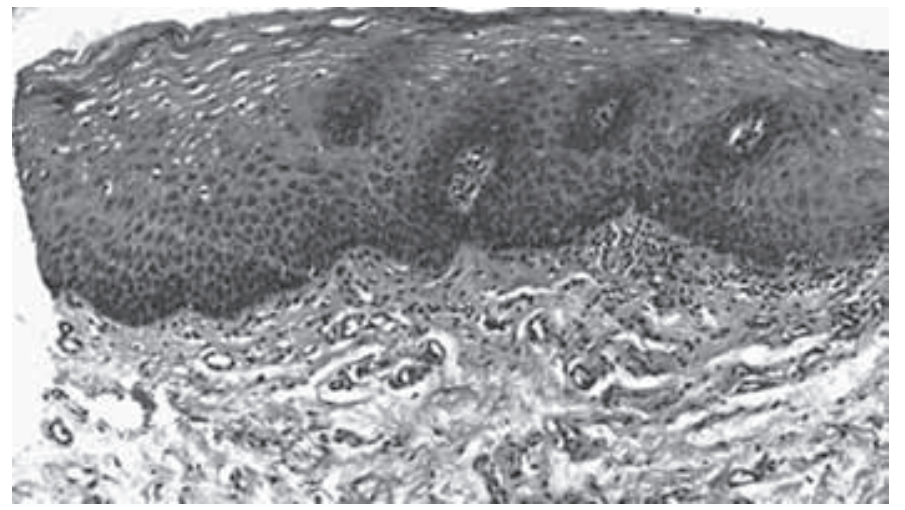

Figure 3. Epithelium and Lamina própria (magnification 10x) - histological features: Acanthosis, thickening of basal layer, band-like mononuclear inflamatory infiltrate of lamina própria

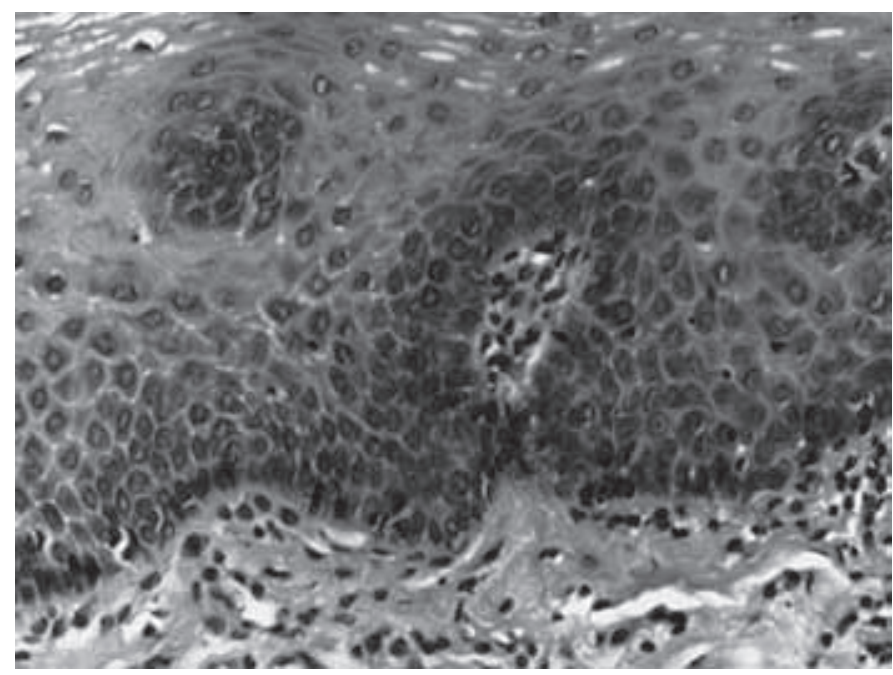

Figure 4. Epithelium (magnification 40x) - histological features: spongiosis, keratinocytic atipia, exocytosis

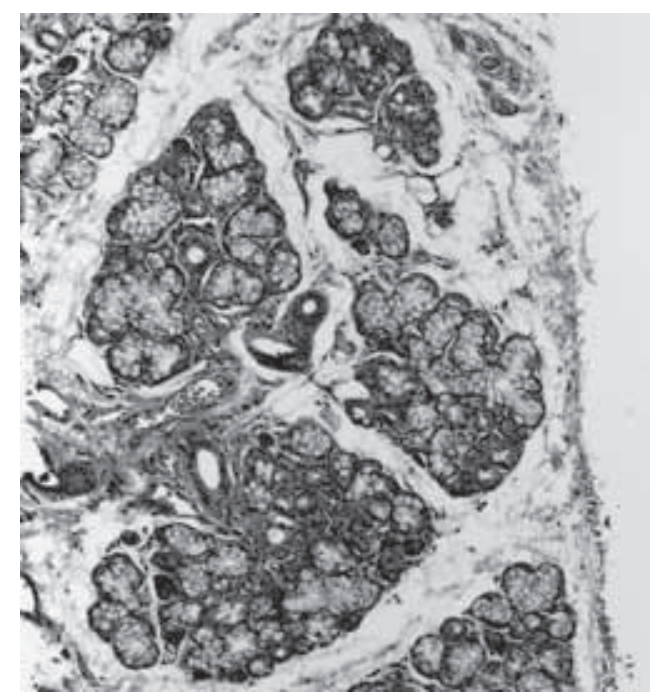

Figure 5. Minor salivary gland (magnification 40x) - histological features: Lymphocytes around \& migrating into acinar units, acinar degeneration, periductal chronic infiltrate, periductal fibrosis, intersticial fibrosis

The recommendations of the consensus document suggested an incisional biopsy of a non-ulcerated site and at least five lobules of the underlying gland, since the mucosal and glandular disease may not be synchronous and the disease may be at various stages of involvement.

The ability of the dentist and the oral pathologist to diagnose and treat oral cGVHD plays a major role in improving supportive care and quality of life to these patients. There is a consensus in the related literature regarding the importance of oral care providers and dental surgeons, as part of a multiprofessional team in diagnosing and treating cGVHD. The diagnosis of oral GVHD commencing 4 years after transplantation and coincident to the withdrawing the immunosuppression is uncommon. The treatment of oral cGVHD is important to the maintenance of the quality of life in long-term survivors of hematopoietic stem cell transplantation.

\section{RESUMO}

Doença crônica do enxerto contra o hospedeiro é a principal complicação tardia após Transplante de células-tronco hematopoieticas (TCTH) alogênico e a principal causa de morbidade e perda da qualidade de vida em longo prazo dos sobreviventes de TCTH. Envolvimento oral ocorre em cerca de 53\% - 70\% nos receptores de medula óssea e de células-tronco de sangue periférico, respectivamente. Relatamos um caso de início tardio de GVHD oral crônico e discutimos o papel dos prestadores de cuidados de saúde oral no diagnóstico precoce e manejo da doença. Além disso, o desenvolvimento de GVHDc oral, quatro anos após o transplante, coincidindo com a retirada da imunossupressão é mais incomum e mostra a importância de acompanhar o envolvimento da cavidade oral após o transplante alogênico.

Descritores: Rejeição do enxerto, Doenças da boca, Transplante de Medula Óssea

\section{REFERENCES}

1. Laughlin MJ, Eapen M, Rubinstein P et al. Outcomes after transplantation of cord blood or bone marrow from unrelated donors in adults with leukemia. N Engl J Med. 2004;351:2265-75.
2. Eisen D, Essel J, Vroun ER. Oral cavity complications of bone marrow transplantation. Semin Cutan Med Surg. 1997;16(4):265-72.

3. Filipovich AH, Weisdorf D, Pavletic S et al. National Institutes of Health consensus development project on criteria for clinical trials in chronic graft-versus-host disease: 
I. Diagnosis and staging working group report. Biol Blood Marrow Transplant. 2005 Dec;11(12):945-56.

4. Jacobsohn DA, Montross S, Anders V et al. Clinical importance of confirming or excluding the diagnosis of chronic graft-versus-host disease. Bone Marrow Transplant. 2001;28(11):1047-51

5. Pavletic SZ, Smith LM, Bishop MR et al. Prognostic Factors of Chronic Graft-VersusHost Disease After Allogeneic Blood Stem-Cell Transplantation. Am J Hematol. $2005 ; 78(4): 265-74$.

6. Santos, PSS; Lima, RB; Magalhães, MHCG. Graft-Versus-Host-Disease in patients submitted to bone marrow transplantation - case report. RPG. Rev Pos-Grad (USP) 2005;12:506-511.

7. Schubert MM, Sullivan KM, Morton TH et al. Oral manifestations of chronic graftv-host disease. Arch Intern Med. 1984;144(8):1591-5.

8. Busca A, Locatelli F, Vai S et al. Clinical grading of oral chronic graft-versus-host disease in 104 consecutive adult patients. Haematologica. 2005;90(4):567-9.

9. Akpek G, Zahurak ML, Piantadosi S et al. Development of a prognostic model for grading chronic graft-versus-host disease. Blood. 2001;97(5):1219-26.
10. Nakamura S, Hiroki A, Shinohara M et al. Oral involvement in chronic graft-versushost disease after allogeneic bone marrow transplantation. Oral Surg Oral Med Oral Pathol Oral radiol Endod. 1996;82(5):556-63.

11. Shulman HM, Kleiner D, Lee SJ et al. Histopathologic diagnosis of chronic graftversus-host disease: National Institutes of Health Consensus Development Project on Criteria for Clinical Trials in Chronic Graft-versus-Host Disease: II. Pathology Working Group Report. Biol Blood Marrow Transplant. 2006;12(1):31-47.

12. Martin PJ, Weisdorf D, Przepiorka D et al. National Institutes of Health Consensus Development Project on Criteria for Clinical Trials in Chronic Graft-versus-Host Disease: VI. Design of Clinical Trials Working Group report. Biol Blood Marrow Transplant. 2006;12(5):491-505.

13. França CM, Domingues-Martins M, Volpe A et al. Severe oral manifestations of chronic graft-vs.-host disease. J Am Dent Assoc. 2001;132(8):1124-7.

14. Coracin FL, Pizzigatti Correa ME, Camargo EE et al. Major salivary gland damage in allogeneic hematopoietic progenitor cell transplantation assessed by scintigraphic methods. Bone Marrow Transplant. 2006;37(10):955-9.

15. Alborghetti MR, Corrêa ME, Adam RL et al. Late effects of chronic graft-vs.-host disease in minor salivary glands. J Oral Pathol Med. 2005; 34(8):486-93. 